\title{
Perbedaan Pengetahuan dan Sikap Remaja tentang Infeksi Menular Seksual di SMA/SMK Perkotaan dan Pedesaan
}

\author{
Erald J. Lanes, ${ }^{1}$ Suzanna P. Mongan, ${ }^{2}$ John J.E. Wantania
}

\author{
${ }^{1}$ Program Studi Pendidikan Dokter Fakultas Kedokteran Universitas Sam Ratulangi, Manado, \\ Sulawesi Utara, Indonesia \\ ${ }^{2}$ Bagian Ilmu Kebidanan dan Kandungan Fakultas Kedokteran Universitas Sam Ratulangi/ \\ RSUP Prof. Dr. R. D. Kandou, Manado, Sulawesi Utara, Indonesia \\ Email: 17011101114@student.unsrat.ac.id
}

\begin{abstract}
Premarital sexual behavior in adolescence is a high risk factor for sexually transmitted infections. Sexually transmitted infections (STIs) are infections that are generally transmitted through sexual contact. Differences in social, cultural, and economic factors were found to affect the incidence and prevalence of sexually transmitted infections between different groups in a population. These are likely caused by differences in the knowledge and attitudes of adolescents living in urban and rural areas. This study was aimed to obtain the differences in the level of knowledge and attitudes toward STIs of adolescents in urban and rural area schools. This was a descriptive study with a cross-sectional design conducted on 50 adolescents of urban senior high schools and 50 adolescents of rural senior high schools/vocational high schools. Questionnaires were distributed via email by using Google form. The results showed that adolescents living in urban areas had good knowledge about STIs meanwhile adolescents living in rural areas had fair knowledge. The attitudes about STIs of most adolescents living in urban areas and rural areas were good. In conclusion, adolescents living in urban areas had better knowledge about STIs than those living in rural areas, however, there was no significant difference in attitudes about STI between the two regions. Equal distribution of education in Indonesia is needed in urban as well as in rural areas.
\end{abstract}

Keywords: sexually transmitted infections, adolescents, knowledge, attitudes, urban and rural

\begin{abstract}
Abstrak: Perilaku seksual pranikah pada usia remaja merupakan faktor risiko tinggi terhadap infeksi menular seksual (IMS). Infeksi menular seksual merupakan infeksi yang umumnya ditularkan melalui hubungan seksual. Perbedaan faktor sosial, kultural maupun ekonomi dapat memengaruhi insiden dan prevalensi IMS antara kelompok yang berbeda dalam suatu populasi. Hal tersebut kemungkinan besar disebabkan oleh adanya perbedaan pengetahuan dan sikap remaja yang tinggal di wilayah perkotaan dan pedesaan. Penelitian ini bertujuan untuk mengetahui perbedaan tingkat pengetahuan dan sikap remaja terhadap IMS di sekolah wilayah perkotaan dan pedesaan. Jenis penelitian ialah deskriptif dengan desain potong lintang dan kuesioner didistribusikan secara daring menggunakan Google Form. Responden ialah 50 remaja di SMA wilayah perkotaan dan 50 remaja di SMA/SMK wilayah pedesaan. Hasil penelitian mendapatkan bahwa pengetahuan remaja tentang IMS pada siswa SMA perkotaan sebagian besar berada dalam kategori baik sedangkan pada siswa SMA/SMK pedesaan sebagian besar berada dalam kategori cukup. Sikap remaja tentang IMS pada siswa SMA/SMK perkotaan dan pedesaan sebagian besar baik. Simpulan penelitian ini ialah remaja perkotaan memiliki pengetahuan yang lebih baik mengenai IMS dibandingkan remaja di pedesaan namun tidak terdapat perbedaan sikap remaja yang bermakna mengenai IMS antara kedua wilayah. Pemerataan pendidikan di Indonesia dibutuhkan di wilayah perkotaan dan pedesaan.
\end{abstract}

Kata kunci: infeksi menular seksual, remaja, pengetahuan, sikap, perkotaan dan pedesaan 


\section{PENDAHULUAN}

Remaja digambarkan sebagai masa kehidupan seseorang yang bukan lagi anakanak tetapi belum dewasa. Pertumbuhan dan perkembangan fisik remaja disertai dengan pematangan seksual dan sering kali mengarah ke hubungan intim. Perilaku seksual pranikah pada usia remaja merupakan faktor risiko tinggi terhadap infeksi menular seksual (IMS). ${ }^{1}$

Infeksi menular seksual merupakan infeksi yang ditularkan melalui hubungan seksual baik secara vaginal, anal dan oral. Beberapa IMS dapat ditularkan melalui darah yang terkontaminasi dari seorang ibu ke anak yang belum lahir. ${ }^{1}$ IMS disebabkan oleh beberapa jenis bakteri, virus, parasit dan jamur. Infeksi tersebut memiliki pengaruh yang sangat besar pada kesehatan seksual dan reproduksi di seluruh dunia. ${ }^{2}$

Berdasarkan data WHO didapatkan 1 juta IMS setiap harinya. Pada tahun 2016 diperkirakan 376 juta infeksi baru yaitu: klamidia (127 juta), gonore (87 juta), sifilis (6,3 juta) dan trikomoniasis (156 juta). ${ }^{3}$ Proporsi IMS di Asia Selatan dan Asia Tenggara merupakan proporsi terbesar yang selanjutnya diikuti oleh Sub-Sahara Afrika, Amerika Latin dan Karibia. ${ }^{4}$

Di Indonesia ditemukan 3 IMS terbanyak yaitu kondiloma akuminata, gonore dan infeksi genital non-spesifik berdasarkan data dari 12 Rumah Sakit (RS) Pendidikan selama periode 2007-2011..$^{5}$ Berdasarkan laporan Niode ${ }^{6}$ tahun 2016 tentang infeksi saluran reproduksi (ISR) dan IMS di RSUP. Prof. Dr. R. D. Kandou Manado periode 2012-2014 terdapat 404 pasien. Infeksi terbanyak yang ditemukan yaitu kandidosis vulvovaginalis $(23,27 \%)$, selanjutnya diikuti oleh vaginosis bakterial $(18,07 \%)$ dan kondiloma akuminata $(17,33 \%)$. Berdasarkan distribusi usia, kelompok usia 15-24 tahun didapatkan sebesar 29,95\%.

Data dari UNFPA dan WHO menunjukkan 1 dari 20 remaja tertular IMS per tahun. ${ }^{7}$ Menurut estimasi CDC terdapat 20 juta IMS baru setiap tahun dan sebagian orang yang terinfeksi ialah remaja usia 15 sampai 24 tahun. $^{8}$ Hal ini menunjukkan bahwa IMS yang terjadi pada kelompok usia remaja masih tinggi. Peneliti menduga hal ini terjadi karena kurangnya pengetahuan dan sikap remaja tentang IMS.

Data epidemiologi menunjukkan adanya perbedaan faktor sosial, kultural dan ekonomi dalam insiden dan prevalensi IMS antara kelompok yang berbeda dalam suatu populasi. ${ }^{1}$ Remaja yang tinggal di perkotaan dapat lebih mudah mengakses informasi dan teknologi dibandingkan di pedesaan seperti tersedianya jaringan internet. ${ }^{9}$ Hal ini menunjukkan adanya perbedaan antara kehidupan masyarakat yang tinggal di daerah perkotaan dan pedesaan. Peneliti menduga adanya perbedaan yang dapat memengaruhi pengetahuan dan sikap masyarakat yang tinggal di daerah perkotaan dan pedesaan.

\section{METODE PENELITIAN}

Jenis penelitian ini ialah deskriptif komparatif dengan desain potong lintang. Penelitian dilakukan pada siswa di Kota Manado (SMAN 9 Binsus Manado dan SMAN 4 Manado) dan Desa Tombulu (SMAN 1 Tombulu dan SMKN 1 Tombulu) pada bulan Oktober-November 2020. Kuesioner didistribusikan secara daring menggunakan Google Form.

Populasi penelitian ini ialah seluruh siswa SMAN 9 Binsus Manado, SMAN 4 Manado, SMAN 1 Tombulu dan SMKN 1 Tombulu. Responden penelitian ini sebanyak 100 siswa yang dibagi menjadi 50 siswa dari wilayah perkotaan dan 50 siswa dari wilayah pedesaan yang dipilih menggunakan teknik random sampling. Variabel penelitian ini yaitu pengetahuan dan sikap remaja tentang IMS di SMA/SMK perkotaan dan pedesaan.

\section{HASIL PENELITIAN}

Tabel 1 memperlihatkan bahwa proporsi terbesar karakteristik responden berdasarkan jenis kelamin secara keseluruhan di sekolah wilayah perkotaan maupun wilayah pedesaan merupakan responden perempuan yaitu terdapat 63 siswi (63\%) sedangkan sisanya yaitu responden yang berjenis kelamin laki-laki sebanyak 37 siswa (37\%).

Tabel 2 memperlihatkan bahwa proporsi terbesar karakteristik responden berdasar- 
kan usia secara keseluruhan di sekolah wilayah perkotaan maupun wilayah pedesaan merupakan responden yang berusia 17 tahun yaitu terdapat 38 siswa (38\%) sedangkan proporsi terkecil ialah siswa yang berusia 13 tahun yaitu hanya terdapat 1 siswa $(1 \%)$.

Tabel 3 menunjukkan bahwa proporsi terbesar responden berdasarkan sumber informasi secara keseluruhan di sekolah wilayah perkotaan maupun wilayah pedesaan, responden mendapatkan sumber informasi tentang IMS dari berbagai informasi campuran yaitu sebanyak 45 siswa (45\%), diikuti oleh sumber informasi dari media massa yaitu sebanyak 33 siswa (33\%).

Tabel 4 memperlihatkan bahwa perbedaan pengetahuan remaja tentang IMS yakni sebagian besar siswa SMA perkotaan memiliki pengetahuan yang baik yaitu sebanyak 27 siswa (27\%), sedangkan tingkat pengetahuan pada siswa SMA pedesaan sebagian besar memiliki tingkat pengetahuan cukup yaitu sebanyak 29 siswa (29\%). Dengan demikian terdapat perbedaan pengetahuan siswa tentang IMS antara ke-dua wilayah.

Tabel 1. Gambaran karakteristik responden berdasarkan jenis kelamin

\begin{tabular}{ccccccc}
\hline \multirow{2}{*}{ Jenis } & \multicolumn{4}{c}{ Asal Sekolah } & \multicolumn{2}{c}{ Jumlah } \\
Kelamin & \multicolumn{2}{c}{ SMA Perkotaan } & \multicolumn{2}{c}{ SMA Pedesaan } & \multicolumn{2}{c}{} \\
& F & $\%$ & F & $\%$ & F & $\%$ \\
\hline Laki-laki & 15 & $15 \%$ & 22 & $22 \%$ & 37 & $37 \%$ \\
Perempuan & 35 & $35 \%$ & 28 & $28 \%$ & 63 & $63 \%$ \\
Total & 50 & $50 \%$ & 50 & $50 \%$ & 100 & $100 \%$ \\
\hline
\end{tabular}

Tabel 2. Gambaran karakteristik responden berdasarkan usia

\begin{tabular}{ccccccc}
\hline \multirow{2}{*}{$\begin{array}{c}\text { Usia } \\
\text { (tahun) }\end{array}$} & \multicolumn{3}{c}{ SMA Perkot Sekolah } & \multicolumn{2}{c}{ SMA Pedesaan } & \multicolumn{2}{c}{ Jumlah } \\
& F & $\%$ & F & $\%$ & F & $\%$ \\
\hline 13 & 1 & $1 \%$ & 0 & $0 \%$ & 1 & $1 \%$ \\
14 & 2 & $2 \%$ & 4 & $4 \%$ & 6 & $6 \%$ \\
15 & 12 & $12 \%$ & 1 & $1 \%$ & 13 & $13 \%$ \\
16 & 21 & $21 \%$ & 12 & $12 \%$ & 33 & $33 \%$ \\
17 & 13 & $13 \%$ & 25 & $25 \%$ & 38 & $38 \%$ \\
18 & 1 & $1 \%$ & 8 & $8 \%$ & 9 & $9 \%$ \\
Total & 50 & $50 \%$ & 50 & $50 \%$ & 100 & $100 \%$ \\
\hline
\end{tabular}

Tabel 3. Gambaran karakteristik responden berdasarkan sumber informasi

\begin{tabular}{lllllll}
\hline \multirow{2}{*}{ Sumber Informasi } & \multicolumn{4}{c}{ Asal Sekolah } & \multicolumn{2}{l}{ Jumlah } \\
& SMA Perkotaan & \multicolumn{2}{l}{ SMA Pedesaan } & F \\
& F & $\%$ & F & $\%$ & F & $\%$ \\
\hline Orang tua & 0 & $0 \%$ & 5 & $5 \%$ & 5 & $5 \%$ \\
Sekolah & 10 & $10 \%$ & 7 & $7 \%$ & 17 & $17 \%$ \\
Media massa & 16 & $16 \%$ & 17 & $17 \%$ & 33 & $33 \%$ \\
Campuran & 24 & $24 \%$ & 21 & $21 \%$ & 45 & $45 \%$ \\
Total & 50 & $50 \%$ & 50 & $50 \%$ & 100 & $100 \%$ \\
\hline
\end{tabular}


Tabel 5 memperlihatkan bahwa pertanyaan yang paling banyak dijawab benar pada variabel pengetahuan di SMA wilayah perkotaan ialah pertanyaan nomor 1 (definisi IMS) sebanyak 50 siswa (100\%) dan pertanyaan yang paling sedikit dijawab benar ialah pertanyaan nomor 3 (penyebab IMS), yaitu sebanyak 27 siswa (54\%). Pertanyaan yang paling banyak dijawab benar di SMA wilayah pedesaan ialah pertanyaan nomor 1 sebanyak 50 siswa $(100 \%)$ dan pertanyaan yang paling sedikit dijawab benar ialah pertanyaan nomor 3, yaitu sebanyak 10 siswa $(20 \%)$.

Tabel 6. memperlihatkan bahwa sikap remaja tentang IMS yakni sebagian besar siswa SMA perkotaan memiliki sikap yang baik tentang IMS yaitu sebanyak 42 siswa (42\%). Demikian pula dengan siswa SMA/ SMK pedesaan sebagian besar memiliki sikap yang baik yaitu sebanyak 35 siswa $(35 \%)$. Dengan demikian sikap siswa tentang IMS tidak memiliki perbedaan.

Tabel 7 memperlihatkan bahwa pertanyaan yang paling banyak dijawab benar pada variabel sikap di SMA wilayah perkotaan ialah pertanyaan nomor 4 (Orang yang berganti-ganti pasangan seksual berisiko untuk terkena IMS), 5 (Akan menyarankan orang yang memiliki gejala IMS utuk segera berobat ke dokter) dan 7 (Kebutuhan remaja akan penyuluhan kesehatan seksual agar terhindar dari bahaya IMS) sebanyak 50 siswa $(100 \%)$. Pertanyaan yang paling sedikit dijawab benar ialah pertanyaan nomor 8 (Berdiskusi mengenai masalah seksual adalah hal tabu) sebanyak 35 siswa (70\%). Pertanyaan yang paling banyak dijawab benar pada variabel sikap di SMA wilayah pedesaan ialah pertanyaan nomor 4 dan 7 sebanyak 48 siswa (96\%) dan pertanyaan yang paling sedikit dijawab benar ialah pertanyaan nomor 8 , yaitu sebanyak 26 siswa (52\%).

Tabel 4. Pengetahuan remaja tentang infeksi menular seksual di SMA/SMK perkotaan dan pedesaan

\begin{tabular}{|c|c|c|c|c|c|c|}
\hline \multirow{3}{*}{ Pengetahuan } & \multicolumn{4}{|c|}{ Asal Sekolah } & \multirow{2}{*}{\multicolumn{2}{|c|}{ Jumlah }} \\
\hline & \multicolumn{2}{|c|}{ SMA Perkotaan } & \multicolumn{2}{|c|}{ SMA Pedesaan } & & \\
\hline & $\mathrm{F}$ & $\%$ & $\mathrm{~F}$ & $\%$ & $\mathrm{~F}$ & $\%$ \\
\hline Buruk & 2 & $2 \%$ & 5 & $5 \%$ & 7 & $7 \%$ \\
\hline Kurang & 2 & $2 \%$ & 6 & $6 \%$ & 8 & $8 \%$ \\
\hline Cukup & 19 & $19 \%$ & 29 & $29 \%$ & 48 & $48 \%$ \\
\hline Baik & 27 & $27 \%$ & 10 & $10 \%$ & 37 & $37 \%$ \\
\hline Total & 50 & $50 \%$ & 50 & $50 \%$ & 100 & $100 \%$ \\
\hline
\end{tabular}

Tabel 5. Distribusi frekuensi jawaban responden pada variabel pengetahuan di SMA wilayah perkotaan dan pedesaan

\begin{tabular}{ccccccccccccc}
\hline \multirow{2}{*}{$\begin{array}{c}\text { Nomor } \\
\text { Pertanyaan }\end{array}$} & \multicolumn{1}{c}{ SMA Perkotaan } & \multicolumn{10}{c}{ Sawaban Responden } \\
& Benar & \multicolumn{1}{c}{ Salah } & Jumlah & \multicolumn{3}{c}{ Benar } & \multicolumn{2}{c}{ Salah } & \multicolumn{2}{c}{ Jumlah } \\
& F & $\%$ & F & $\%$ & F & $\%$ & F & $\%$ & F & $\%$ & F & $\%$ \\
\hline 1 & 50 & $100 \%$ & 0 & $0 \%$ & 50 & $100 \%$ & 50 & $100 \%$ & 0 & $0 \%$ & 50 & $100 \%$ \\
2 & 46 & $92 \%$ & 4 & $8 \%$ & 50 & $100 \%$ & 37 & $74 \%$ & 13 & $26 \%$ & 50 & $100 \%$ \\
3 & 27 & $54 \%$ & 23 & $46 \%$ & 50 & $100 \%$ & 10 & $20 \%$ & 40 & $80 \%$ & 50 & $100 \%$ \\
4 & 48 & $96 \%$ & 2 & $4 \%$ & 50 & $100 \%$ & 49 & $98 \%$ & 1 & $2 \%$ & 50 & $100 \%$ \\
5 & 45 & $90 \%$ & 5 & $10 \%$ & 50 & $100 \%$ & 39 & $78 \%$ & 11 & $22 \%$ & 50 & $100 \%$ \\
6 & 31 & $62 \%$ & 19 & $38 \%$ & 50 & $100 \%$ & 24 & $48 \%$ & 26 & $52 \%$ & 50 & $100 \%$ \\
7 & 44 & $88 \%$ & 6 & $12 \%$ & 50 & $100 \%$ & 33 & $66 \%$ & 17 & $34 \%$ & 50 & $100 \%$ \\
8 & 33 & $66 \%$ & 17 & $34 \%$ & 50 & $100 \%$ & 34 & $68 \%$ & 16 & $32 \%$ & 50 & $100 \%$ \\
\hline
\end{tabular}


Tabel 6. Sikap remaja tentang infeksi menular seksual di SMA/SMK perkotaan dan pedesaan

\begin{tabular}{|c|c|c|c|c|c|c|}
\hline \multirow{3}{*}{ Sikap } & \multicolumn{4}{|c|}{ Asal Sekolah } & \multirow{2}{*}{\multicolumn{2}{|c|}{ Jumlah }} \\
\hline & \multicolumn{2}{|c|}{ SMA Perkotaan } & \multicolumn{2}{|c|}{ SMA Pedesaan } & & \\
\hline & $\mathrm{F}$ & $\%$ & $\mathrm{~F}$ & $\%$ & $\mathrm{~F}$ & $\%$ \\
\hline Buruk & 0 & $0 \%$ & 1 & $1 \%$ & 1 & $1 \%$ \\
\hline Kurang & 0 & $0 \%$ & 5 & $5 \%$ & 5 & $5 \%$ \\
\hline Cukup & 8 & $8 \%$ & 9 & $9 \%$ & 17 & $17 \%$ \\
\hline Baik & 42 & $42 \%$ & 35 & $35 \%$ & 77 & $77 \%$ \\
\hline Total & 50 & $50 \%$ & 50 & $50 \%$ & 100 & $100 \%$ \\
\hline
\end{tabular}

Tabel 7. Distribusi frekuensi jawaban responden pada variabel sikap di SMA wilayah perkotaan dan pedesaan

\begin{tabular}{ccccccccccccc}
\hline $\begin{array}{c}\text { Nomor } \\
\text { Pertanyaan }\end{array}$ & \multicolumn{4}{c}{ SMA Perkotaan } & \multicolumn{4}{c}{ Jawaban Responden } \\
& \multicolumn{2}{c}{ Benar } & \multicolumn{3}{c}{ Salah } & \multicolumn{3}{c}{ Jumlah } & \multicolumn{3}{c}{ Benar } & \multicolumn{3}{c}{ Salah } & Jumlah \\
& F & $\%$ & F & $\%$ & F & $\%$ & F & $\%$ & F & $\%$ & F & $\%$ \\
\hline 1 & 47 & $94 \%$ & 3 & $6 \%$ & 50 & $100 \%$ & 41 & $82 \%$ & 9 & $18 \%$ & 50 & $100 \%$ \\
2 & 45 & $90 \%$ & 5 & $10 \%$ & 50 & $100 \%$ & 43 & $86 \%$ & 7 & $14 \%$ & 50 & $100 \%$ \\
3 & 39 & $78 \%$ & 11 & $22 \%$ & 50 & $100 \%$ & 36 & $72 \%$ & 14 & $28 \%$ & 50 & $100 \%$ \\
4 & 50 & $100 \%$ & 0 & $0 \%$ & 50 & $100 \%$ & 48 & $96 \%$ & 2 & $4 \%$ & 50 & $100 \%$ \\
5 & 50 & $100 \%$ & 0 & $0 \%$ & 50 & $100 \%$ & 47 & $94 \%$ & 3 & $6 \%$ & 50 & $100 \%$ \\
6 & 45 & $90 \%$ & 5 & $10 \%$ & 50 & $100 \%$ & 40 & $80 \%$ & 10 & $20 \%$ & 50 & $100 \%$ \\
7 & 50 & $100 \%$ & 0 & $0 \%$ & 50 & $100 \%$ & 48 & $96 \%$ & 2 & $4 \%$ & 50 & $100 \%$ \\
8 & 35 & $70 \%$ & 15 & $30 \%$ & 50 & $100 \%$ & 26 & $52 \%$ & 24 & $48 \%$ & 50 & $100 \%$ \\
\hline
\end{tabular}

Hasil Uji Mann Whitney mendapatkan bahwa terdapat 2 hasil yang berbeda yakni variabel pengetahuan menunjukkan bahwa adanya perbedaan pengetahuan remaja tentang IMS di SMA/SMK perkotaan dan pedesaan dengan nilai $\mathrm{p}=0,000 \quad(<0,05)$. Berbeda halnya dengan variabel sikap yang menunjukkan bahwa tidak adanya perbedaan sikap tentang IMS di SMA/SMK perkotaan dan pedesaan dengan nilai $\mathrm{p}=0,062$ $(>0,05)$.

\section{BAHASAN}

\section{Pengetahuan tentang IMS}

Pada penelitian yang dilakukan pada SMA/SMK wilayah perkotaan dan pedesaan, jumlah responden sebanyak 100 siswa yang dibagi menjadi 2 kelompok, yaitu 50 siswa di wilayah perkotaan dan 50 siswa di wilayah pedesaan. Dari hasil penelitian pada siswa SMA/SMK wilayah perkotaan seba- gian besar didapatkan tingkat pengetahuan remaja tentang IMS dalam kategori baik yaitu sebanyak 27 siswa (54\%), sedangkan tingkat pengetahuan remaja tentang IMS pada SMA/SMK wilayah pedesaan sebagian besar dalam kategori cukup yaitu sebanyak 29 siswa (58\%). Dengan demikian pengetahuan siswa tentang IMS di wilayah perkotaan dan pedesaan memiliki perbedaan. Menurut Kandar, ${ }^{9}$ masyarakat yang tinggal di wilayah perkotaan lebih mudah menyesuaikan diri terhadap perubahan sosial, yaitu dalam menerima informasi dengan fasilitas yang lebih mudah didapatkan seperti internet dan telekomunikasi. ${ }^{9}$ Menurut Notoadmodjo, ${ }^{10}$ pengetahuan seseorang diperoleh dari faktor internal seperti jasmani dan rohani. Selain itu terdapat juga faktor eksternal yang berasal dari pendidikan, media massa, status ekonomi, hubungan sosial, pengalaman dan usia. 
Hasil penelitian yang didapatkan dari SMA wilayah perkotaan bertolak belakang dengan penelitian yang dilakukan oleh Syafardi et al $^{11}$ di SMA/SMK di wilayah Palaran kota Samarinda, yang menunjukkan tingkat pengetahuan yang kurang $(45,7 \%)$. Hasil penelitian ini cukup selaras dengan penelitian yang dilakukan oleh Triningtyas ${ }^{12}$ di SMA Al-Asiyah Cibinong kota Bogor, yang menunjukkan tingkat pengetahuan cukup sebesar $77,3 \%$ dan hanya $0,8 \%$ responden dengan tingkat pengetahuan rendah. Hal ini sesuai dengan penelitian yang dilakukan oleh Pandjaitan ${ }^{13}$ pada remaja di SMA Frater Don Bosco Manado dengan tingkat pengetahuan remaja baik $(50 \%)$. Hasil penelitian yang didapatkan dari SMA/SMK wilayah pedesaan hampir sesuai dengan penelitian yang dilakukan oleh Purwanti ${ }^{14}$ pada remaja di desa Karang Tanjung Sidoarjo dengan tingkat pengetahuan tentang IMS kurang. Namun hasil penelitian ini sesuai dengan penelitian yang dilakukan oleh Patonah dan Irwanto ${ }^{15}$ pada remaja di desa Alasgung Bojonegoro dengan hasil tingkat pengetahuan cukup $(55,2 \%)$.

Hasil penelitian ini menunjukkan seluruh responden (100\%) baik dari SMA yang berada di wilayah perkotaan ataupun SMA/SMK di wilayah pedesaan, mengetahui bahwa IMS adalah infeksi yang ditularkan terutama melalui hubungan seksual. Hal ini berbeda dengan hasil penelitian Triningtyas $^{12}$ pada SMA Al-Asiyah Cibinong Bogor yang mendapatkan hasil $54,5 \%$ responden yang mengetahui pengertian IMS. Namun hasil penelitian sesuai dengan penelitian Pandjaitan ${ }^{13}$ di Manado, yaitu sebagian besar responden mengetahui pengertian dari IMS (98\%).

Terdapat kurang lebih 30 jenis mikroba antara lain bakteri, virus dan parasit yang dapat ditularkan melalui hubungan seksual maupun tidak melalui hubungan seksual. ${ }^{3}$ Pada penelitian ini sebagian besar responden dari SMA/SMK di wilayah perkotaan ataupun di wilayah pedesaan dapat menentukan salah satu jenis dari IMS yaitu sebanyak $83 \%$ responden secara keseluruhan. Hasil penelitian ini sesuai dengan penelitian sebelumnya yang dilakukan oleh Simamora ${ }^{16}$ di Medan pada remaja di SMA Negeri 1 Medan yaitu sebanyak $81,1 \%$ remaja yang menjawab benar. Meskipun responden tidak diminta menyebutkan satu per satu jenis IMS, namun $83 \%$ responden dapat membedakan jenis IMS dengan penyakit lain.

Pada penelitian ini, 54\% responden dari SMA perkotaan mengetahui tentang penyebab dari IMS sedangkan responden dari SMA/SMK pedesaan hanya $20 \%$ yang mengetahui tentang penyebab dari IMS. Berdasarkan hasil tersebut, siswa yang tinggal di wilayah perkotaan memiliki pengetahuan yang lebih baik tentang penyebab dari IMS walaupun masih ada sebagian belum mengetahui tentang penyebab IMS. Siswa yang tinggal di wilayah pedesaan, hanya sebagian kecil yang dapat menjawab benar.

Sebanyak 97\% responden secara keseluruhan baik dari SMA wilayah perkotaan dan pedesaan mengetahui tentang cara penularan IMS. Tingginya pengetahuan tentang cara penularan IMS, diharapkan responden menghindari seks bebas yang merupakan faktor risiko terkena IMS. Hasil ini sesuai dengan penelitian Pandjaitan ${ }^{13}$ di Manado yang mendapatkan $97 \%$ remaja mengetahui tentang penularan IMS.

Pada hasil penelitian ini, sebanyak $84 \%$ responden secara keseluruhan di SMA/SMK wilayah perkotaan dan pedesaan, mengetahui tentang gejala dari IMS salah satunya ialah keputihan yang berbau. Hasil penelitian Simamora ${ }^{16}$ dari Medan berbeda dengan penelitian ini dan hanya mendapatkan $52 \%$ responden yang mengetahui gejala dari IMS. Hasil penelitian ini tidak jauh berbeda dengan penelitian yang dilakukan oleh Pandjaitan ${ }^{13}$ di Manado yang mendapatkan sebanyak $80 \%$ responden mengetahui salah satu gejala dari IMS.

Dalam hasil penelitian didapatkan sebanyak $62 \%$ responden dari SMA wilayah perkotaan dan $48 \%$ responden dari SMA/ SMK wilayah pedesaan yang mengetahui jenis IMS berdasarkan gejalanya. Dapat dilihat bahwa persentase dari kedua wilayah tidak terlalu jauh berbeda namun masih belum banyak responden yang menjawab 
dengan benar. Hal ini menunjukkan bahwa masih terdapat sebagian remaja yang belum mengetahui beberapa jenis IMS berdasarkan gejala yang ada.

Berbagai macam komplikasi dapat terjadi pada IMS. Sebanyak $77 \%$ responden secara keseluruhan baik di wilayah perkotaan dan pedesaan mengetahui komplikasi dari IMS salah satunya yaitu infertilitas. Hasil ini jauh berbeda dengan penelitian yang dilakukan oleh Syafardi et al ${ }^{11} \mathrm{di}$ Samarinda, yang mendapatkan 35\% responden mengetahui komplikasi dari IMS. Pengetahuan siswa tentang komplikasi IMS yang baik, diharapkan dapat membuat siswa untuk lebih berhati-hati dan menghindari perilaku yang berisiko terkena IMS.

Sebanyak $67 \%$ siswa secara keseluruhan di SMA wilayah perkotaan dan SMA/ SMK wilayah pedesaan mengetahui cara pencegahan agar tidak tertular IMS salah satunya yaitu dengan cara abstinensia atau menunda kegiatan seksual. Hasil penelitian ini sesuai dengan hasil yang didapatkan oleh Syafardi et al ${ }^{11}$ di Samarinda yang mendapatkan sebanyak $66 \%$ responden mengetahui cara pencegahan IMS yaitu dengan cara tidak melakukan kegiatan seksual. Dengan berbekal pengetahuan tentang pencegahan IMS ini, diharapkan siswa dapat menghindari perilaku seks bebas dan dapat menurunkan prevalensi IMS yang tinggi.

\section{Sikap tentang IMS}

Dari hasil penelitian pada siswa SMA/ SMK wilayah perkotaan sebagian besar memiliki sikap yang baik terhadap IMS, yaitu sebanyak 42 siswa (84\%). Begitu juga dengan SMA/SMK wilayah pedesaan, sebagian besar memiliki sikap yang baik terhadap IMS yaitu sebanyak 35 siswa (70\%). Berdasarkan hasil penelitian, tidak didapatkan perbedaan sikap remaja terhadap IMS antara remaja di wilayah perkotaan dan wilayah pedesaan. Menurut Azwar ${ }^{17}$ terdapat beberapa hal yang dapat memengaruhi sikap yaitu, pengalaman pribadi, orang lain, budaya, media massa, lembaga pendidikan dan agama. Selain dipengaruhi beberapa faktor, setiap individu memiliki selektifitas dan daya pilih sendiri terhadap suatu hal yang harus diputuskan. ${ }^{18}$

Hasil penelitian ini sesuai dengan hasil penelitian yang dilakukan oleh Pandjaitan ${ }^{13}$ di salah satu SMA di kota Manado, yang mendapatkan $71 \%$ siswa memiliki sikap yang baik terhadap IMS dan tidak ada siswa yang memiliki sikap buruk. Hasil ini juga sesuai dengan penelitian yang dilakukan oleh Mularsih ${ }^{19}$ di desa Muntal Pakintelan, yang mendapatkan $84,2 \%$ responden memiliki sikap setuju tentang infeksi menular seksual.

Berdasarkan hasil penelitian, sebanyak $88 \%$ responden secara keseluruhan dari wilayah perkotaan dan pedesaan yang setuju bahwa mereka tidak akan tertular IMS walaupun berada di dalam satu ruangan yang sama dengan orang yang terkena IMS. Penelitian ini hampir sesuai dengan penelitian yang dilakukan oleh Syafardi et $\mathrm{al}^{11}$ yang mendapatkan sebesar $41,5 \%$ responden sangat tidak setuju dan $22,3 \%$ tidak setuju untuk menjauhi orang yang terkena IMS. Meskipun sebagian besar remaja setuju, namun masih ada sebagian kecil remaja yang memilih untuk tidak berada di dekat orang yang terkena IMS. Hal ini menunjukkan bahwa masih terdapat sikap negatif terhadap orang yang terkena IMS.

Dalam penelitian didapatkan sebanyak 88\% responden secara keseluruhan dari wilayah perkotaan dan pedesaan yang setuju dengan cara mencegah IMS yaitu tidak melakukan hubungan seks pra-nikah dan sebanyak $75 \%$ responden tidak setuju dengan mengonsumsi obat sebelum berhubungan seksual dapat mencegah IMS. Penelitian ini sesusai dengan penelitian oleh Pandjaitan ${ }^{13}$ yang mendapatkan sebanyak 88\% responden yang setuju dengan tidak melakukan hubungan seks pra-nikah untuk mencegah terjadinya IMS dan sebanyak $72 \%$ responden tidak setuju bahwa minum obat sebelum berhubungan seksual dapat mencegah IMS.

Hasil penelitian di wilayah perkotaan dan pedesaan, sebanyak $98 \%$ responden setuju bahwa berganti-ganti pasangan saat melakukan hubungan seksual memiliki risiko untuk terkena IMS. Selain itu, sebanyak 95\% dari keseluruhan responden 
memilih sikap setuju untuk memiliki pergaulan yang sehat dan beraktifitas bersama banyak teman dalam mencegah terjadinya IMS. Hasil penelitian menunjukkan bahwa siswa dari wilayah perkotaan maupun pedesaan memiliki sikap yang baik dalam melakukan pencegahan IMS.

Dalam hasil penelitian ini didapatkan 97\% responden yang memilih sikap setuju untuk memberikan saran kepada orang yang memiliki gejala IMS untuk segera mencari pengobatan. Sementara itu, sebanyak $98 \%$ responden setuju bahwa mereka membutuhkan penyuluhan tentang kesehatan seksual agar terhindar dari bahaya IMS. Kebutuhan penyuluhan tentang kesehatan seksual harus diberikan kepada remaja karena hanya $61 \%$ responden yang setuju bahwa berdiskusi mengenai masalah seksual merupakan hal yang tidak tabu. Masih terdapat 39\% respon-den yang beranggapan bahwa berdiskusi mengenai masalah seksual itu adalah hal tabu. Hal ini mungkin terjadi karena masih adanya stigma masyarakat terhadap orang dengan penyakit infeksi menular seksual.

\section{SIMPULAN}

Remaja perkotaan memiliki pengetahuan yang lebih baik mengenai IMS dibandingkan remaja di pedesaan namun tidak terdapat perbedaan sikap remaja yang bermakna mengenai IMS antara kedua wilayah

Hasil penelitian ini diharapkan dapat memotivasi siswa untuk lebih peduli dalam meningkatkan pengetahuan tentang IMS. Perlu adanya edukasi tentang kesehatan reproduksi dari pihak sekolah dan pemerintah serta pemerataan dalam hal pendidikan baik di wilayah perkotaan dan pedesaan. Diharapkan hasil penelitian ini dapat digunakan sebagai pengembangan ilmu yang lebih luas dan mendalam.

\section{Konflik Kepentingan}

Penulis menyatakan tidak terdapat konflik kepentingan dalam studi ini.

\section{DAFTAR PUSTAKA}

1. WHO. Handout for Module A Introduction.
Geneva, 2018.; p. 6.

2. Fuchs W, Brockmeyer NH. Sexually transmitted infections. J Ger Soc Dermatology (JDDG). 2014;12(6):451-64.

3. WHO. Sexually transmitted infections (STIs) [Internet]. [cited 2020 Oct 15]. Available from: https://www.who.int/ news-room/ fact-sheets/detail/sexuallytransmitted-infections-(stis)

4. Gewirtzman A, Bobrick L, Conner K, Tyring SK. Epidemiology of sexually transmitted infections. In: Sexually Transmitted Infections and Sexually Transmitted Diseases. Heidelberg Berlin: Springer, 2011. p. 13-34.

5. Indriatmi W. Epidemiologi infeksi menular seksual. Disampaikan pada Simposium Sexually Transmitted Infection Arising Concern. 2012.

6. Niode N. Infeksi saluran reproduksi dan infeksi menular seksual di Poliklinik Kulit dan Kelamin RSUP Prof. Dr. R. D. Kandou, Manado. Manado: Bagian/SMF Ilmu Kesehatan Kulit dan Kelamin Fakultas Kedokteran Universitas Sam Ratulangi. 2016;43. Avai-lable from: http://www. perdoski.or.id/doc/mdvi/fulltext/42/ 274/5_Artikel_Asli.pdf

7. BKKBN. Infeksi Menular Seksual dan HIV/ AIDS. Buku Suplemen Bimbingan Teknis Kesehatan Reproduksi: Infeksi Menular Seksual dan Hiv/Aids. Jakarta: BKKBN, 2012; p. 3.

8. Centers for Disease Control. Sexually transmitted disease surveillance in Britain. $\mathrm{Br}$ Med J. 2016;289(6437):99-100.

9. Jamaludin AN. Sosiologi Perkotaan Memahami Masyarakat Kota dan Problematikanya. Sosiologi Perkotaan Vol 2. Bandung: CV Pustaka Setia, 2015.

10. Notoatmodjo S. Ilmu Kesehatan Masyarakat Prinsip-Prinsip Dasar. Jakarta: Rineka Cipta, 2011; p. 57-65.

11. Syafardi D, Jaya I, Widiantoro S, Wiranegara T. Gambaran pengetahuan dan sikap remaja SMA 6 SMK 11 dan SMK 19 di Wilayah Palaran Samarinda terkait infeksi menular seksual [Skripsi]. Samarinda: Fakultas Kedokteran Universitas Mulawarman; 2014.

12. Triningtyas $N$. Tingkat pengetahuan remaja tentang infeksi menular seksual di SMA Al-Asiyah Cibinong Bogor Tahun 2015 [Skripsi]. Jakarta: Universitas Islam Negeri Syarif Hidayatullah. 2015; 
13. Pandjaitan M. Gambaran pengetahuan dan sikap terhadap infeksi menular seksual pada remaja di SMA Frater Don Bosco Manado [Skripsi]. Manado: Fakultas Kedokteran Universitas Sam Ratulangi; 2017.

14. Purwanti R. Gambaran pengetahuan tentang penyakit menular seksual pada remaja di Desa Karang Tanjung Kecamatan Candi Kabupaten Sidoarjo. [cited 2020 Dec 15]; Available from: http://digilib. unusa.ac.id/data_pustaka-8541.html

15. Patonah S, Irwanto A. Gambaran pengetahuan remaja tentang penyakit menular seksual (Hiv/Aids) di Desa Alasgung Kec Sugihwaras. Asuhan Kesehat J
Penelit Kesehat. 2015;6(1):32-6.

16. Simamora A. Pengetahuan dan sikap remaja tentang infeksi menular seksual Di SMA Negeri 7 Medan [Skripsi]. Medan: Universitas Sumatera Utara; 2014.

17. Azwar S. Sikap Manusia: Teori dan Pengukurannya. Yogyakarta: Pustaka Pelajar, 2012.

18. Gerungan WA. Psikologi Sosial. Bandung: Refika Aditama, 2002; p. 1-99.

19. Mularsih S. Gambaran pengetahuan dan sikap remaja tentang infeksi menular seksual di Desa Muntal Pakintelan Kota Semarang [Skripsi]. Semarang: Sekolah Tinggi Ilmu Kesehatan Mitra Husada Karanganyar; 2020. 